\title{
Editorial: paradoxes
}

This issue of the journal includes three papers on paradoxes. Two of them were submitted to the 2019 Philosophy Essay Prize, on The Significance of Paradoxes, for which authors were asked to consider the philosophical use of paradox in any area. We received a number of excellent entries and it was impressive to see the range of topics where reflection on paradoxes is relevant: there were papers on ethics, epistemology, logic, metaphysics, philosophy of language, philosophy of law, philosophy of mind, political philosophy, art and literature, and the meaning of life. The winning essay, published here, is Georgi Gardiner's 'Profiling and Proof: are statistics safe?'. We also publish a highly commended runner up: Martin Pleitz's 'Paradox as a Guide to Ground'. The third paper is a commissioned piece on paradoxes by Roy Sorensen and Mark Sainsbury which considers the identification, nature, and enumeration of paradoxes.

The issue also features a transcript of Susan Neiman's Royal Institute of Philosophy/Royal Society of Edinburgh Annual Lecture 'Justice and History', delivered in Edinburgh on 25 November. The publication of the various RIP annual lectures is intended to meet the journal's goal of enabling RIP members and other readers keep in touch with the Institute's activities all over the UK.

We also publish reviews of books on a decent life by Todd May (reviewed by Jake Wojtowicz), on idealism by Govinda Chandra Dev (reviewed by Ralph Walker), and on the place of God in Kant's metaphysics by Edward Kanterian (reviewed by Jonathan Egid).

The next issue of the journal will be dedicated to the work of Early Career Researchers.

We are also excited to announce details of this year's essay prize. The topic for the 2020 Competition is Knowledge, Truth and Power in an Online World.

Advances in IT have made possible things that seemed pure science-fiction even two decades ago, for instance, real-time audiovisual communication is now accessible to anyone almost anywhere. This has transformed commercial and financial transactions, the dissemination of information and news in all media formats, political and personal relationships - even romance. This development is bound to have a radical impact on how we approach traditional philosophical problems about, for example, knowledge, the justification of belief, political power and influence, or fairness. We welcome 


\section{Editorial}

submissions on these and related topics, addressing questions such as: Does an online world bring new sources of justification, or new forms of scepticism, or both? Does the internet 'extend the mind' and, if so, how? Who controls and regulates what may be communicated, or vouches for its credentials? And who ought to control and regulate them, if anybody? Who owns data? How should the massive profits it generates be distributed or taxed? And how might philosophical reflection on earlier periods of similar rapid change help us understand and respond to the transformations now in progress?

The winner will receive $£ 2,500$ and their essay will be published in Philosophy.

The submission deadline is 1st October 2020. Entries will be considered by a panel of judges and the winner announced at the beginning of 2021. The winning entry will be published in the April 2021 issue of Philosophy.

In assessing entries priority will be given to originality, clarity of expression, breadth of interest, and potential for advancing discussion. All entries will be deemed to be submissions to Philosophy and more than one may be published. In exceptional circumstances the prize may be awarded jointly, in which case the financial component will be divided, but the hope is to select a single prize-winner.

Maria Alvarez

Bill Brewer 